\title{
軸受転用トラクションドライブの設計と性能評価
}

\section{Design and Performance Evaluation of Traction Drive Reducer Made by Bearing}

\author{
○学 白鳥 拓也 (室蘭工大院)
}

Takuya SHIRATORI, Muroran Institute of Technology, 27-1, Mizumoto-cho, Muroran, Hokkaido

$\begin{array}{ccc}\text { 学 山口 曜 } \text { (室蘭工大) } & \text { 正 成田 幸仁 } \quad \text { (室蘭工大) } & \text { 正 風間 俊治 (室蘭工大) } \\ \text { Yo YAMAGUCHI, } & \text { Yukihito NARITA, } & \text { Toshiharu KAZAMA, } \\ \text { Muroran Institute of Technology } & \text { Muroran Institute of Technology } & \text { Muroran Institute of Technology }\end{array}$

Key Words: Tribology, Traction Drive, Bearing, Efficiency, Machine Element

\section{1. 緒論}

近年, 家庭用の小型ロボットの開発が進んでおり, そのよ うなロボットに用いる小型で静肃性の高い減速機が求めら れている、ロボット用の小型減速機としては波動歯車減速機 があるが，この装置は効率が最大で $65 \%$ 程度であり，振動や 騒音の発生などの問題がある.

そこで, 本研究では低コストな玉軸受を転用して低振動・ 低騒音の小型トラクションドライブ減速機を設計し, 実験に より効率や静肃性を評価することを目的とする.

\section{2. 軸受転用トラクションドライブ}

玉軸受と遊星ローラ型トラクションドライブは構造が似 ている. そのため, 玉軸受をトラクション油で潤滑し, 内外 輪と転動体の接触部に法線力を加えることで, トラクション ドライブとして使用することができると考えられる.

Fig.1 に装置の概略図を示す．保持器と軸を一体としたも のを製作し, 外輪を固定, 内輪を入力, 保持器を出力として 使用する.

\section{3. 軸受の選定}

トラクションドライブ部にはアンギュラ玉軸受を使用す る.アンギュラ玉軸受には接触角 $\alpha$ があるため軸方向の力を 与えることで法線力を得ることができる.

軸受のピッチ円直径を $D_{p w}$, 転動体直径を $D_{w}$ とすると, 軸受を減速機としたときの減速比 $e_{s}$ は式(1)となる.

$$
e_{s}=\frac{2 D_{p w}}{D_{p w}-D_{w} \cos \alpha}
$$

軸受の内外輪の大きさが同じ場合， $\alpha$ が小さいほうが大き な減速比を得られ, $\alpha=15^{\circ}$ の $7200 \mathrm{C}$ では $e_{s}=2.72$ となる.

次にトルク伝達に必要な推力 $F_{a}$ を求める. 推力が大きい ほど摩擦によるトルク損失などが増大するため $F_{a}$ は小さい ほうがよい. 入力トルクを $T_{i n}$, 出力トルクを $T_{\text {out }}$, トラクシ ヨン係数を $\mu$ とすると $F_{a}$ は式(2)となる.

$$
F_{a}=\frac{2 T_{o u t} \sin \alpha}{\mu D_{p w}}=\frac{2 T_{i n} e_{S} \sin \alpha}{\mu D_{p w}}
$$

式より， $\alpha$ が小さいほど, 必要な推力 $F_{a}$ は小さくなること が分かる.

次にスピンを計算する. スピンとは接触棈円の回転運動の ことで，スピンが増大すると局所的な温度上昇が発生し， $\mu$ が低下するため，スピンは小さいことが望ましい。

式(3)の $\beta, \gamma$ を用いて, 軸受のスピン角速度比 $\omega_{s} / \omega_{\text {roll }}$ は, 式(4)で表される(1).

$$
\beta=\tan ^{-1} \frac{\sin \alpha}{\cos \alpha+\gamma}, \gamma=\frac{D_{p w}}{D_{w}}
$$

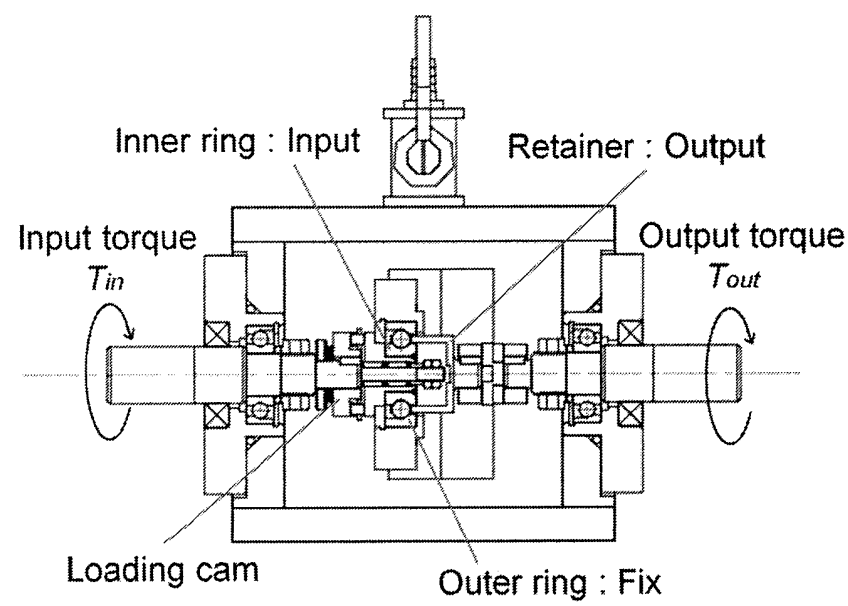

Fig. 1 Schematic of traction drive reducer

Table 1 Specification and calculation value of $7200 \mathrm{C}$

\begin{tabular}{lll|c}
\hline Outer diameter & $D$ & $\mathrm{~mm}$ & 30 \\
Bore diameter & $d$ & $\mathrm{~mm}$ & 10 \\
Pitch diameter & $D_{p w}$ & $\mathrm{~mm}$ & 20 \\
Ball diameter & $D_{w}$ & $\mathrm{~mm}$ & 5.5 \\
Speed ratio $\quad e_{s}$ & & & 2.72 \\
Loading force $\quad F_{a}\left(T_{\text {in }}=1 \mathrm{Nm}, \mu=0.07\right) \quad \mathrm{N}$ & 1005.7 \\
Spin angular velocity ratio $\omega_{s} / \omega_{\text {roll }} \quad \%$ & 11 \\
\hline
\end{tabular}

$$
\frac{\omega_{s}}{\omega_{\text {roll }}}=(1-\gamma \cos \alpha) \tan (\alpha-\beta)+\gamma \sin \alpha
$$

上式より，スピンの大きさは $\alpha$ に大き影響され， $\alpha$ が小 さいほどスピンも小さいことが分かる.

以上の計算結果から減速機に使用する軸受は接触角が小 さいものが適していると考え， $\alpha=15^{\circ}$ の 7200C を使用するこ ととした. Table 1 に 7200C の諸元と各計算值を示す.

\section{4. 設計と性能予測}

4-1 推カカムの設計 トルクにかかわらず高い効率を得る にはトルクに応じて推力が変化することが望ましい.よって 推力発生機構として推力カムを使用することとし, 適切な力 ムリード角を計算する.

カムリード角 $\alpha_{c a m}$ は, カムの有効径 $r_{c a m}$ と入カトルク $T_{i n}$, 推力 $F_{a}$ を用いて式(5)で表される(2).

$$
\alpha=2 \tan ^{-1}\left(\frac{T_{\text {in }}}{F_{a} r_{c a m}}\right)
$$

式(2)より得られる $T_{\text {in }}=1 \mathrm{Nm}, F a=1005.7 \mathrm{~N}$ を式(5)に代入し, $r_{\text {cam }}$ を $10 \mathrm{~mm}$ とした場合 $\alpha_{\text {cam }}$ は $11.36^{\circ}$ となる. 
4-2 効率計算 動力伝達効率 $\eta$ は入出力の回転速度 $N_{i n}, N_{\text {out }}$ とトルク $T_{i n}, T_{\text {out }}$ より式(6)で表され, 速度伝達効率 $\eta_{S}$ とト ルク伝達効率 $\eta_{T}$ の積となる.

$$
\eta=\frac{N_{\text {out }}}{N_{\text {in }}} \frac{T_{\text {out }}}{T_{\text {in }}}=\eta_{S} \eta_{T}
$$

$\eta_{s}$ は内輪と転動体および外輪と転動体のすべり率 $C_{r 1}, C_{r 2}$ より式(7)で表される.

$$
\eta_{s}=\left(1-C_{r 1}\right)\left(1-C_{r 2}\right)
$$

すべり率 $C_{r 1}, C_{r 2}$ はトラクション油膜の弾塑性モデルより トラクションカーブを計算することで求めた ${ }^{(3)}$. 設計に用い た $\mu=0.07$ となる点の $C_{r 1}, C_{r 2}$ を用いて $\eta_{s}$ を求めたところ, $\eta_{s}$ は最大で $99 \%$ 程度となった。

$\eta_{T}$ は軸受のトルク損失 $t$ から求める. $t$ は軸受にかかる荷 重 $F$ と摩擦係数 $\mu_{b}$ を用いて式(8)のように表され， $\eta_{T}$ は式(9) のようになる(4).

$$
\begin{aligned}
t & =\mu_{b} F \frac{D_{p w}}{2} \\
\eta_{T} & =1-\frac{t}{T_{\text {out }}}
\end{aligned}
$$

本装置では, 入力軸を支持する軸受が推力力ムからの反力 を受け，そこから $t$ が生じる. $\mu_{b}$ は 0.0045 とした ${ }^{(5)}$. 入力軸 を支える軸受 7001A は $D_{p w}=20.5 \mathrm{~mm}$ であり， $\eta_{T}$ は $98.3 \%$ とな る.

$T_{\text {out }}$ と $\eta$ のグラフを Fig.2 に示す. 計算の結果, $\eta$ は最大で 97.3\%となった.

\section{5. 実験}

5-1 実験手順 Fig.3 に実験装置の写真を示す. モータより 動力を与え, ブレーキの負荷トルクを変化させながら， $N_{i n}$, $N_{\text {out }}$ と $T_{\text {in }}, T_{\text {out }}$ をトルク計により計測した. $N_{\text {in }}$ を 1000,2000 , $3000 \mathrm{rpm}$ の 3 通りとし， $T_{i n}$ はモータの定格トルクである $1.3 \mathrm{Nm}$ まで計測した.

潤滑油は出光興産製トラクション油 TDF32 を使用し油浴 潤滑とした。油の特性值を Table 2 に示す.

また, 静肃性の検証のため, トラクションドライブ部を接 続した場合と，接続せずモータとトルク計のみを駆動した場 合の騒音を計測し, 差分をとることでトラクションドライブ 部の騒音を計測した。

5-2 結果と考察 減速比 $e_{s}$ と出力トルク $T_{\text {out }}$ のグラフを Fig.4 に, 動力伝達効率 $\eta$ と $T_{\text {out }}$ のグラフを Fig.2 に示す.

実験で得られた $e_{s}$ はほぼ一定で 2.58 程度であり, 計算値 2.72 より小さい值となった。これは軸受外輪がベアリングホ ルダに完全に固定されていないために外輪が回転し，転動体 の公転速度が増加したためだと考えられる. そのため外輪の 固定方法を改良することで減速比の改善ができると思われ る.

動力伝達効率 $\eta$ は最大で $79 \%$ 程度となり計算值よりも低い 值となった.これは転動体と保持器の摩擦による損失が主な 原因だと考えられる. 保持器の材質や形状の改良により摩擦 損失を低下させ，効率の改善ができると思われる．

騒音は回転速度 1000，2000，3000 rpm で計測し，トラクシ ヨンドライブ部を接続した状態で $54.6 ， 61.1 ， 64.3 \mathrm{~dB}$ ，モー タとトルク計のみで $52.7,58.2,63.2 \mathrm{~dB}$ を記録した. 騒音の 差は 1 3dB となるため, この装置の主な騒音はモータによる ものであり,トラクションドライブ部の騒音は非常に小さい と言える。

\section{6. 結論}

ロボット用の小型減速機への適用のため, 軸受転用トラク ションドライブ減速機の性能評価をすることを目的とし, 装 置設計と実験を行った. 得られた結果を以下に示す.

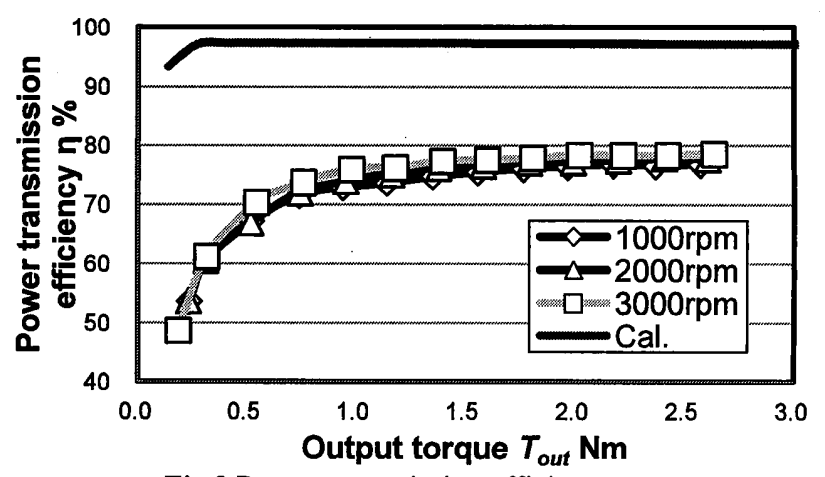

Fig.2 Power transmission efficiency

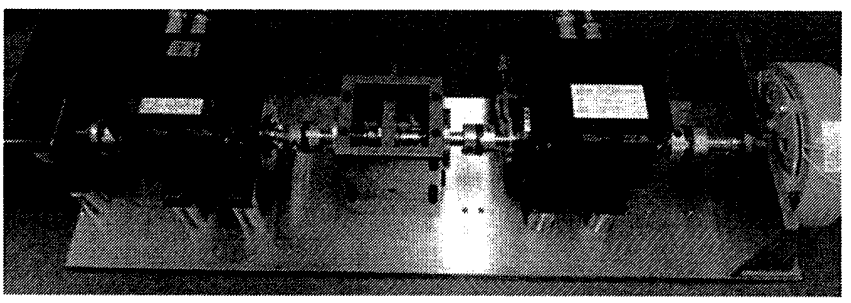

Fig.3 Photograph of test rig

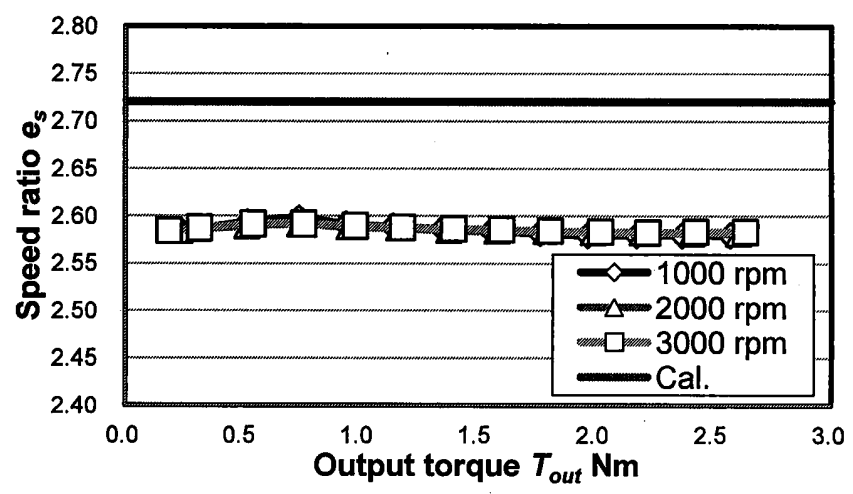

Fig.4 Speed ratio

Table 2 Properties of traction oil

\begin{tabular}{c|c|c|c|c|c}
\hline $\begin{array}{c}\text { Kinematic viscosity } \\
{\left[\mathrm{mm}^{2} / \mathrm{sec}\right]}\end{array}$ & $\begin{array}{c}\text { Density } \\
{\left[\mathrm{g} / \mathrm{cm}^{3}\right]}\end{array}$ & \multicolumn{3}{|c}{$\begin{array}{c}\text { Pressure viscosity coefficient } \\
{\left[\mathrm{GPa}^{-1}\right]}\end{array}$} \\
\hline $313 \mathrm{~K}$ & $373 \mathrm{~K}$ & $288 \mathrm{~K}$ & $303 \mathrm{~K}$ & $313 \mathrm{~K}$ & $373 \mathrm{~K}$ \\
\hline 32.83 & 5.65 & 0.96 & 28.5 & 26.1 & 16.4 \\
\hline
\end{tabular}

1. 計算による性能予測を行い,トラクションドライブに転用 するのは接触角の小さな軸受が適することがわかった.

2. 減速比は 2.58 となり, 計算值よりも小さな值となった. 外輪を固定することで改善できると思われる.

3. 動力伝達効率は $79 \%$ となり, 転動体と保持器の摩擦を低 減する必要があることが分かった.

4. 騒音の計測により,トラクションドライブ部の騒音は非常 に小さいことを確認した.

\section{参考文献}

(1) Tedric A. Harris, Michael N. Kotzalas : Advanced Concepts of Bearing Technology, Taylor \& Francis, (2007)

(2) 山中将ら: 交差軸トラクションドライブの研究, 機論 $\mathrm{C}$, 67-656, (2001), 255-260

（3）田中裕久：トロイダル CVT, コロナ社, (2000)

（4）錦林英一: 転がり軸受マニュアル，日本規格協会, (1999)

(5) 田中裕久, 窪野英和 : スラスト玉軸受のトラクション油 中のスピンモーメント，機論 C, 56-524, (1990), 97-101 